\title{
Measuring The Most Effective Spike Position in Volleyball Match
}

\author{
Agung Wahyudi ${ }^{1}$, Imam Santosa ${ }^{2}$, Agus Pujianto ${ }^{3}$ \\ \{agungwahyudi@mail.unnes.ac.id ${ }^{1}$, santosoimam29@mail.unnes.ac.id ${ }^{2}$, guspu- \\ jianto.73@mail.unnes.ac.id $\left.{ }^{3}\right\}$
}

Universitas Negeri Semarang, Semarang, Indonesia ${ }^{1,2,3}$

\begin{abstract}
This research was conducted to find out which position is the most effective in order to score points faster. A descriptive quantitative research was conducted with survey and observation methods at volleyball matches participated by 24 elite Indonesian athletes at the 2019 ASEAN School Games. Observation and survey were made at UIN Walisongo Semarang Sport Complex on 19-23 July 2019 by observing aspects of attacking positions and the effectiveness of the attack. Data were analyzed using descriptive method to find out which spike position was the most effective. Data showed that the middle position is the most effective position to spike, both for the men's team $(78.3 \%)$ and women's team $(67.31 \%)$. Based on the result, middle position is able to make the attacking team Setter direct the ball using the quick technique. The middle position also can make Setter bounce the ball higher and unreachable by the blocker defense team.
\end{abstract}

Keywords: children volleyball, spike position, ASEAN School Games

\section{Introduction}

Volleyball nowadays, is very popular in various Southeast Asian countries. This can be seen when volleyball is a sport that is competed in the SEA Games and at the student level, such as the ASEAN School Games. In Indonesia, volleyball, these days, has been widely played by the public. This can be seen by the increasing number of volleyball clubs being founded and volleyball matches being conducted at the moment. During the matches and coaching conducted by the club, they have managed to score talented athletes in various regions in Indonesia. Even the Men's Indonesia Volleyball Team was able to become the runner-up since the ASEAN School Games was first held and the Women's Team managed to win first place in 2013-2014. However, the success of an athlete is still determined by the ability and good technique. In volleyball, athletes must have motor skills and the ability to jump. In addition, they also have to hone power, agility, flexibility, and good reaction speed [1]. One technique that is a determining factor in volleyball is Spike. Because this technique is an important part of being able to win a volleyball match [2]. In addition to a capable 
technique, Spiker is also required to have a high posture so he can easily carry out attacks to the opponent's area.

The spike technique in volleyball is not an easy technique to do. The technique has four phases that must be done, namely approach phase, arm cocking phase, acceleration phase, and follow through phase [3]. In addition, the movement of the spike is also influenced by several factors, including the height of the ball when in contact with the player's hand, the tempo of the attack, etc [4]. Therefore, this technique must often be trained and carried out to get maximum results, even a professional volleyball athlete spikes 40,000 times a year [5]. However, mastering the technique alone is not enough to guarantee victory in volleyball matches. Players must know which position is the most effective in making spikes so they can immediately score points.

Spike technique can be performed from various positions, including positions four, three, two, and rear position (attack line). From some of these positions, a coach must pay attention to the level of difficulty and the most effective position to generate numbers so that he can arrange teams based on the types of players correctly. However, not all coaches understand the importance of using skills or tactics in sports matches. In fact, a match that does not have a directed tactic can affect the final outcome of the game and will psychologically affect the mental condition of athletes and team cohesiveness on the field $[6,7]$.

Volleyball as a sport played by six people in a team has several techniques, namely serves, passing, spike, and blocking [8]. When the team has 25 points, the team is declared to win the round. As a team sport, volleyball requires good teamwork so they can work well together. This sport also requires good technical mastery, good physical condition, expertise in managing tactics, and strong mentality to bring maximum achievement [9]. One of the most important techniques in determining victory is a spike because this technique serves to get points quickly. In this technique, there are three effective methods for doing this, including high bait, Tip Technique (slow spike), and sharp spike [10]. Besides, in volleyball matches, knowledge of the court zone is important to learn because the different abilities and actions that must be taken when the team competes are very dependent on the athlete's position in the court [11]. Therefore, the trainer must be able to train various variations and choices of attacks that cannot be predicted because this will be fundamental to the pattern of attacks. By learning the pattern of the game and the possibilities of situations that can occur during a match, this also helps prepare the athlete when competing.

Spike is a technique that can make points in volleyball is an essential skill [2]. Spike movement must be able to make the ball pass over the net, especially if the technique can produce sharp blows to the opponent's area so that his attacks cannot be blocked [12]. There are several stages that must be done so that athletes can make spike movements, consisting of footwork steps, repulsion, release the ball in the air, and landing. In addition, athletes can also practice this technique with several variations of exercises, such as simple open spike exercises, spike exercises with the help of passing, and semi-spike exercises [13]. However, at the beginning of practicing the spike movement, many mistakes that often occur include improper body position, the imposition of the ball with the arm, and swinging the arm that is still wrong [14].

To be able to create spike movements that can make points quickly, the trainer needs to know that there are several different types of athletes in choosing positions that can support the quality of the movement. If the athlete is the Ace Spike type, he 
will more often use high passes when spiking. While athletes with the Quicker type, they feed shorter or with a fast ball and the all-round athlete can use more mixed movements [15]. Spikes have a variety of spike results in accordance with the direction of the ball, such as cross-court spikes and straight spikes. In addition, based on the road curve, the results of the spike movement have several differences, namely strong spike, lob spike, and drive spike. Spike movements can also be divided based on the height of the ball just before the athlete makes an attack, namely open spike, semi spike, and quick spike [16].

From those statements, it can be seen how important it is to understand the tactics and strategy in volleyball, especially the position in spike movements. In fact, the spike movement is the fastest movement to get points, but there is no research on which positions are most effective in spike movements. Though research on matches and tactics in volleyball matches is very important. This can help to optimize the training process by developing strategies and concepts to improve the ability of athletes and teams [7]. Therefore, this research was conducted to find out which position is the most effective in order to score points faster.

\section{Methods}

This is a descriptive quantitative research with survey and observation methods conducted at volleyball matches participated by 24 elite Indonesian athletes at the 2019 ASEAN School Games. Observations were made at UIN Walisongo Semarang Sport Complex on 19-23 July 2019 by observing aspects of attacking positions and the effectiveness of the attack. Data were analyzed using descriptive percentages method so that they could find out which spike position was the most effective with the following criteria:

Tabel 1. Spike Succesfull Criteria

\begin{tabular}{cc}
\hline Percentage & Criteria \\
\hline $76 \%-100 \%$ & Very Good \\
$51 \%-75 \%$ & Good \\
$26 \%-50 \%$ & Average \\
$0 \%-25 \%$ & Poor \\
\hline
\end{tabular}

\section{Results and discussions}

During the observation, the men's team made 259 spikes (blue bar) and the women's team made 314 spikes (orange bars). When viewed in more detail, the men's team mostly made 103 spike movements in the front position and only made 49 spike movements in the back position. This is due to the men's team setters more often directing the ball to the front position using the drive ball. This direction of the ball can 
make it easier for the spiker to strike back because in volleyball matches, the opposing team puts set-upper in the middle to block. However, usually the set-upper has a short height when compared to speakers who tend to have tall bodies so as to make the attacking team superior.

While the women's team made 144 spikes in the front position and only made 48 spikes in the back attack position. This is due to the Setter on the women's team more often carrying out attacks to provide an opportunity for Spiker who master the Open Spike technique to attack by relying on power. This attack becomes difficult to block by Middle-Blocker opponents so that Spiker is easier to get points.

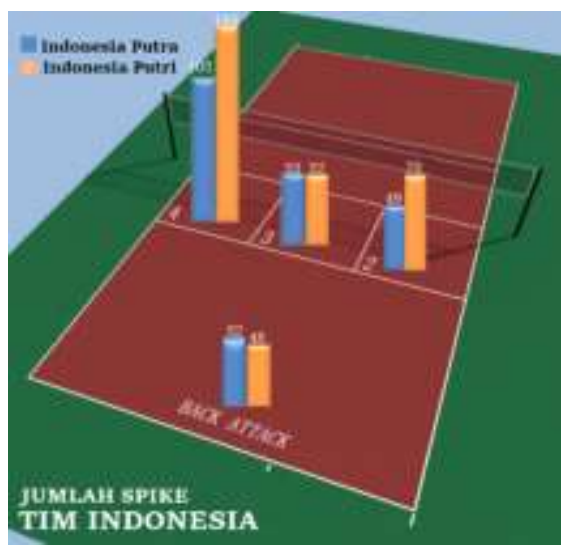

Fig 1. Number of Spike is performed by Athletes

However, if seen from the effectiveness of the spike movement position in getting points, then the middle position is the most effective position to spike, both for the men's team and women's team. In addition, the most common spike movement in the middle position is the Quick Spike.

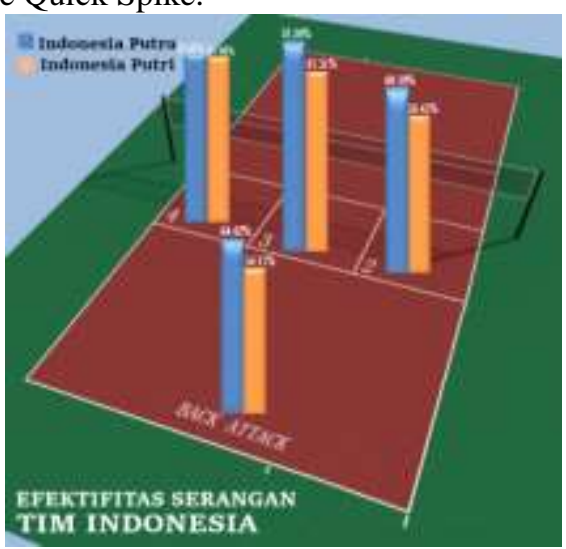

Fig 2. Percentage of Spike Position's Effectiveness 
When talking about strategy in volleyball matches, there are two types of attacks that can be done, namely side-out attacks or counterattacks. Side-out attacks have better effectiveness because it is more balanced to keep attacking during matches. However, with the help of a counterattack, the team also received additional benefits to win the match [17].

The middle position is the most effective because the attacking team Setter can direct the ball using the Quick technique. This technique can create a pattern of attack with a quick type so that it can outwit the opponent. This is also supported by Palao and Ahrabi-Fard's statement that the success of a team to win the match is to put the setter and speaker in the middle position. When Setter is in the middle position with Spiker, he/she has four attack options. Although this is not the only factor in determining the success of the attack, but by doing so, the team has the balance to carry out the second attack. This balance occurs because the Setter is closer to the Spiker so it can counterattack quickly [11]. In addition, the middle position can make Setter create a ball that bounced high and out of the reach of the Blocker of the defense team so that Spiker can carry out powerful and sharp attacks. Such attacks will be more effective than relying on rally points that have the possibility of failing more [18]. Besides, training the team to carry out attacks in a balanced position will help athletes to overcome positions that are not ideal for attacking.

\section{Conclusion}

Based on the results and discussion, it can be concluded that the middle position is the most effective position in spike movements in order to get points faster. It is also an input for the trainer to give more practice portions to techniques that are useful for conducting attacks in the middle position. Later, further research can be done by looking at the weakest attack areas during volleyball matches.

\section{References}

[1] Lehnert, M., Sigmund, M., Lipinska, P., Vařeková, R., Hroch, M., Xaverová, Z., \& Zmijewski, P. Training-induced changes in physical performance can be achieved without body mass reduction after eight week of strength and injury prevention oriented programme in volleyball female players. Biol. Sport. 2017; 34(2):205.

[2] Castro, J., \& Mesquita, I. . Implications of offensive spacing in elite male volleyball attack characteristics. PJSS. 2018; 8(1):114-125.

[3] Kugler, A., Krüger-Franke, M., Reininger, S., Trouillier, H. H., \& Rosemeyer, B. Muscular imbalance and shoulder pain in volleyball attackers. Br. J. Sports Med. 1996; 30(3):256-259.

[4] García-de-Alcaraz, A., Ortega, E., \& Palao, J. M.. Effect of age group on male volleyball players' technical-tactical performance profile for the spike. Int. J. Perf. Anal. Spor. 2015; 15(2):668-686.

[5] Reeser, J. C., Fleisig, G. S., Bolt, B., \& Ruan, M. Upper limb biomechanics during the volleyball serve and spike. Sports Health. 2010; 2(5):368-374.

[6] Nasution, N. S. Hubungan Kekuatan Otot Lengan Dan Percaya Diri Dengan Keterampilan Open Spike Pada Pembelajaran Permainan Bola Voli Atlet Pelatkab Bola Voli Putri Kabupaten Karawang. JUDIKA. 2015;3(2).

[7] Garganta, J. Trends of tactical performance analysis in team sports: bridging the gap between research, training and competition. RPCD. 2009; 9(1):81-89. 
[8] Santoso, D. A. S., \& Irwanto, E. Studi Analisis Biomechanics Langkah Awalan (Footwork Step) Open Spike Dalam Bola Voli Terhadap Power Otot Tungkai. JORPRES. 2018; 14(1):81-89.

[9] Andibowo, T.. Pengaruh Latihan Standing Servis dan Jumping Servis Terhadap Kemampuan Servis Atas Bola Voli. JIP. 2018;4(2).

[10] Muklis. Survey Smash Dalam Kejuaraan Bola Voli Forsa Cup Putri Tahun 2014 / 2015 Di Desa Doko Kecamatan Ngasem Kabupaten Kediri. Kediri: Universitas Nusantara PGRI Kediri; 2014.

[11] Palao, J., \& Ahrabi-Fard, I. Side-out success in relation to setter's position on court in women's college volleyball. Int. J. App. Sports Sci. 2011; 23(1): 155-167.

[12] Supriyadi, S., \& Sunijantoro, A. G. Pengembangan Pola Latihan Penyerangan dalam Permainan Bola Voli Menggunakan Media Audio Visual pada Tim Bola Voli Putri UKM UABV Universitas Negeri Malang. JSS. 2018; 6(1).

[13] Pranopik, M. R. Pengembangan Variasi Latihan Smash Bola Voli. JPSI. 2017; 1(1).

[14] Ilham Surya Fallo, H. Upaya Meningkatkan Keterampilan Smash Permainan Bola Voli Melalui Pembelajaran Gaya Komando. JPO. 2016; 5(1):10-19.

[15] Zuhermandi, Z., Sahputra, R., \& Wakidi, W. Penerapan Media Bola Gantung Untuk Meningkatkan Aktivitas Smash Dalam Permainan Bola Voli Pada Siswakelas XB SMA Negeri 1 Nanga Pinoh. JPJKR. 2015; 2(1):18-29.

[16] Ahmadi, N. Panduan Olahraga Bola Voli. Surakarta: Era Pustaka Utama; 2007.

[17] Kartikaningtyas, E. Pengaruh Metode Latihan Quick Smash Dengan Awalan Dan Tanpa Awalan Terhadap Hasil Quick Smash Dalam Permainan Bolavoli Pada Atlet Putra Klub PORVIT Kabupaten Kudus Tahun 2010. Semarang: Universitas Negeri Semarang; 2011.

[18] Silva, M., Lacerda, D., \& João, P. V. Match analysis of discrimination skills according to the setter defence zone position in high level volleyball. Int. J. Perf. Anal. Spor. 2014; $14(2): 463-472$. 